\title{
A standardized set of metrics to assess and monitor tree invasions
}

\author{
John R. U. Wilson • Paul Caplat • Ian A. Dickie • Cang Hui • Bruce D. Maxwell • \\ Martin A. Nuñez • Aníbal Pauchard · Marcel Rejmánek • David M. Richardson • \\ Mark P. Robertson • Dian Spear • Bruce L. Webber • Brian W. van Wilgen • \\ Rafael D. Zenni
}

\begin{abstract}
Scientists, managers, and policy-makers need functional and effective metrics to improve our understanding and management of biological invasions. Such metrics would help to assess progress towards management goals, increase compatibility across administrative borders, and facilitate comparisons between invasions. Here we outline key characteristics of tree invasions (status, abundance, spatial extent, and impact), discuss how each of these characteristics changes with time, and examine potential metrics to describe and monitor them. We recommend quantifying tree invasions using six
\end{abstract}

J. R. U. Wilson (correspondent) · D. Spear

Invasive Species Programme, South African National

Biodiversity Institute, Kirstenbosch National Research

Centre, Claremont 7735, South Africa

e-mail: john.wilson2@gmail.com

J. R. U. Wilson · C. Hui · D. M. Richardson ·

D. Spear · B. W. van Wilgen

Department of Botany and Zoology, Centre for Invasion

Biology, Stellenbosch University, Private Bag X1,

Matieland 7602, South Africa

P. Caplat

Department of Physical Geography and Ecosystem

Sciences, University of Lund, Sölvegatan 12, 22362 Lund, Sweden

\section{A. Dickie}

Landcare Research, Box 69040, Lincoln 7640,

New Zealand metrics: (a) current status in the region; (b) potential status; (c) the number of foci requiring management; (d) area of occupancy (AOO) (i.e. compressed canopy area or net infestation); (e) extent of occurrence (EOO)(i.e. range size or gross infestation); and (f) observa-tions of current and potential impact. We discuss how each metric can be parameterised (e.g. we include a practical method for classifying the current stage of invasion for trees following Blackburn's unified framework for biological invasions); their potential management value (e.g. EOO provides an indication

\author{
I. A. Dickie \\ Bio-Protection Research Centre, Lincoln University, Box \\ 85084, Lincoln 7647, New Zealand \\ B. D. Maxwell \\ Department of Land Resources and Environmental \\ Sciences, Montana State University, Bozeman, \\ MT 59717, USA \\ M. A. Nuñez \\ Laboratorio Ecotono, INIBIOMA, CONICET, Univ. \\ Nacional del Comahue, Quintral 1250, CP 8400 San \\ Carlos de Bariloche, Argentina \\ A. Pauchard \\ Facultad de Ciencias Forestales, Institute of Ecology and \\ Biodiversity (IEB), Universidad de Concepción, \\ Concepción, Chile
}


of the area over which management is needed); and how they can be used in concert (e.g. combining AOO and EOO can provide insights into invasion dynamics; and we use potential status and threat together to develop a simple risk analysis tool). Based on these metrics, we propose a standardized template for reporting tree invasions that we hope will facilitate cross-species and inter-regional comparisons. While we feel this represents a valuable step towards standardized reporting, there is an urgent need to develop more consistent metrics for impact and threat, and for many specific purposes additional metrics are still needed (e.g. detectability is required to assess the feasibility of eradication).

Keywords Biodiversity assessments .

Biological invasions - Invasive alien species .

Management $\cdot$ Impact $\cdot$ Distribution $\cdot$ Non-native

\section{Introduction}

The science of invasion biology has developed substantially (Gurevitch et al. 2011; Rejmánek 2011) but a recurring criticism of the discipline is the lack of an overall framework linking theory and management

\section{Rejmánek}

Department of Evolution and Ecology, University of California, Davis, Davis, CA 95616, USA

\section{P. Robertson}

Department of Zoology and Entomology, Centre for Invasion Biology, University of Pretoria, Private Bag X20, Pretoria 0028, South Africa

\section{B. L. Webber}

CSIRO Ecosystem Sciences, Private Bag 5, P.O. Wembley, WA 6913, Australia

\section{B. L. Webber}

School of Plant Biology, The University of Western Australia, 35 Stirling Highway, Crawley, WA 6009, Australia

B. W. van Wilgen

CSIR, Natural Resources and the Environment, PO Box 320, Stellenbosch 7599, South Africa

\section{R. D. Zenni}

Department of Ecology and Evolutionary Biology, The University of Tennessee, Knoxville, TN 37996, USA
(Hulme 2003). Although several frameworks have been proposed to advance our understanding of invasions [e.g. Blackburn et al. (2011)], their development has largely been separate from schemes aimed at guiding management or policy (McGeoch et al. 2010; Rew et al. 2007). In contrast, conservation science has a well-established procedure for determining and reporting on the status of species-the IUCN Red Listing Protocol (Mace et al. 2008). Comparable listing efforts in invasion biology have largely focused on opinion (Lowe et al. 2000), but the need for a more quantitative approach is the same as for conservation science. There is an urgent need to move beyond basic lists of invasive taxa, to reporting information at a level that can be used to address various scientific and management needs (Fig. 1).

One of the major problems is that invasions do not follow administrative borders, so measuring the scale of a given invasion (and similarly the risk of extinction) often requires the integration of data collected by multiple stakeholders, agencies, and governments. While most countries are obliged to comply with international obligations (Box 1), data collection standards and the resources available for monitoring and control vary markedly around the world (Supplementary Material 1) (McGeoch et al. 2010; Nunez and Pauchard 2010; P y ̌s ek et al. 2008). Even within a country, different methodologies for quantifying invasions make it difficult to assess how invasions have changed over time (Guo 2011).

Any monitoring of an invasion also needs to be responsive over time-scales that are relevant for management. There is a real danger of responding unnecessarily to naturally variable populations or populations that ultimately fail to invade (Simberloff and Gibbons 2004; Zenni and Nuñez 2013). Nonetheless, responses need to be adaptive and rapid, particularly if eradication is to be a cost-effective option, and sustainable monitoring must have a clear outcome demonstrable in terms of specific agreed indicators. In comparison, for conservation assessments, population trends are measured over at least 10 years, whereas projections are typically framed over a century (Mace et al. 2008).

These issues could be addressed in part by a standardized global baseline for reporting biological invasions. Such information needs to be relatively quick and inexpensive to measure or estimate, but should have the flexibility to be built on in terms of 


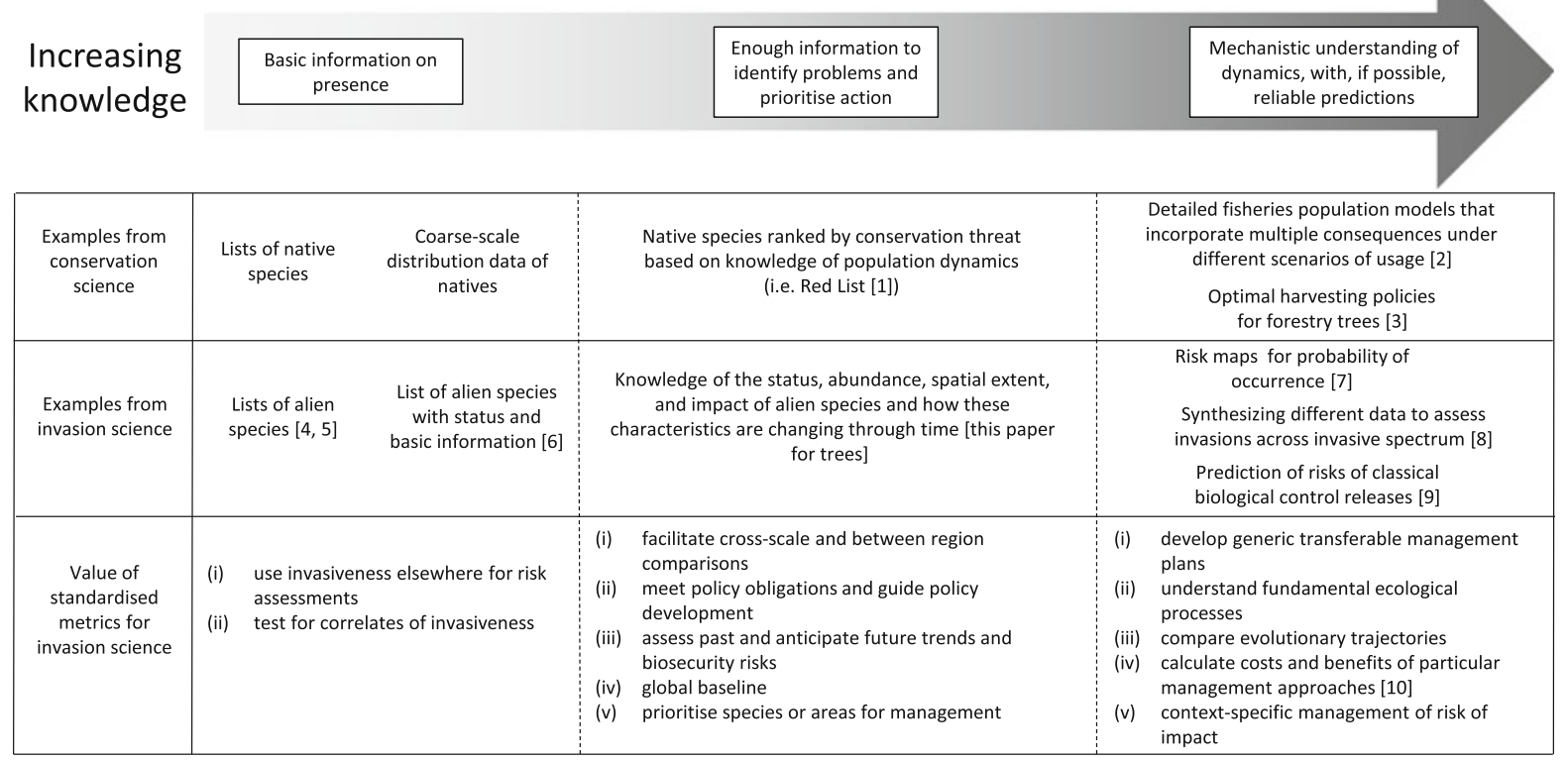

Fig. 1 Conceptual model of how increasing knowledge affects the potential for improving management and understanding, with examples from conservation sciences and invasion science. [1] Mace et al. (2008); [2] Worm et al. (2009); [3] Piazza (2010);

complexity and utility so that impacts (and benefits) can be estimated (Fig. 1). Basic knowledge of whether a species is already present in the country and the current invasion status of its populations are important in determining what strategy and how much effort should be spent on management (Fig. 1). Additional information would facilitate fundamental comparative research in population dynamics, macroecology, and community ecology [work that is currently confounded by underlying differences in the way data on invasions were collected (Stohlgren et al. 2011)]. However, given invasions are context-specific, there is considerable value in deconstructing and evaluating the influence of species identity, dispersal potential, environment, and mode of introduction to develop a mechanistic understanding of the outcome of introductions (Fig. 1). Whatever the level of information available, if it is presented in standardized ways [or collected using common protocols (Gundale et al. 2014)], meta-analyses become powerful analytical tools to explore taxonomic and habitat differences (van Kleunen et al. 2010).

The aim of this paper is to recommend a standardized set of metrics to describe a tree invasion that will
[4] Richardson and Rejmanek (2011); [5] Lowe et al. (2000); [6] Pyšek et al. (2012); [7] Kaplan et al. (2014); [8] Ibanez et al. (in press); [9] Martin and Paynter (2010); [10] van Wilgen and Richardson (2014)

help assess progress towards specific management goals, and increase compatibility across administrative borders, and between invasions. We review metrics used to describe the presence of a species in a specified introduced range, recognising that metrics at different levels (e.g. infra-specific, or at a community level) will provide important additional insights (Pereira et al. 2013). We focus on one specific group -introduced trees. Trees are relatively long-lived, individually identifiable, often are easily detected, can reach high adult densities, and, of course, are usually tall. Trees can therefore dominate plant communities and thus have a high potential to transform landscapes with profound impacts on bio-diversity and ecosystems services (Richardson and Rejma'nek 2011). Trees are an extremely polyphyletic assemblage of around 60,000-100,000 taxa (Petit and Hampe 2006), of which many species have been widely introduced beyond their native range. 434 introduced species (from $<50$ families) are invasive (i.e. $\sim 0.5 \%$ of total diversity) (Rejmanek and Richardson 2013), and more than half of these invaders have been introduced into several different biogeographic regions. 


\begin{abstract}
The listing of alien species is crucial for management and legislation, and many nations have committed to such listing in accordance both with relevant international conventions and national legislation. As signatories to the Convention on Biological Diversity (CBD), most countries are committed to mitigating national threats from alien species (including the enactment of relevant legislation) and reporting on the state of invasion in their countries. At the tenth meeting of the Convention on Biodiversity Conference of the Parties in Aichi, biodiversity targets were set for the period 2011-2020, with target 9 stating that "by 2020, invasive alien species and pathways are identified and prioritized, priority species are controlled or eradicated, and measures are in place to manage pathways to prevent their introduction and establishment' (United Nations Environment Programme 2010). This commits nations to work towards identifying alien species present in their jurisdiction (Supplementary Material 1). The number of alien species in a country has been proposed as an indicator to measure progress towards reaching the CBD 2010 Biodiversity Targets, specifically measuring the threat posed by invasions (McGeoch et al. 2010)
\end{abstract}

But how does one go about developing a comprehensive list of alien species for a given region? Not only is there limited expertise and available information, but the development of lists of alien species is prone to numerous errors such as misidentifications, synonymies, insufficient surveys, impractical data resolution, lack of accessibility of data and insufficient information on native geographic distributions (McGeoch et al. 2012). To ensure consistent and comprehensive listing of alien species, the main sources of error need to be avoided [i.e. investment, consistency, transparency and standardization is required (McGeoch et al. 2012)]. Fundamental to listing alien species is the standardization of taxonomy (e.g. The Angiosperm Phylogeny Group for taxonomic placement, and www.theplantlist.org for accepted nomenclature) and terminology [e.g. see Pysek et al. (2004) for standard definitions of biological invasion terms]. Regional context is an essential qualifier, particularly for large countries where a species might be native in one part of the country but invasive in a different biogeographical area (Bean 2007)

A comprehensive list of alien species would require funding for exhaustive sampling and for sufficient expertise to facilitate identification. This has direct implications on management. Alien species that are most widespread and well known are likely to be recorded first. But in a country with an incomplete alien species inventory, naturalizing species not highlighted as problematic elsewhere are unlikely to be captured before they are widespread or damaging. The completeness of alien species lists varies between countries both as the amount of data available varies (i.e. the extent of local expertise and resources available to sample for and identify new species) and the number of species introduced varies (e.g. owing to differences in the size and sources of trade routes). The relatively short lists of aliens in developing countries are likely due to both effects (McGeoch et al. 2010). Such systematic biases hamper global comparative studies

Many archives have historically ignored alien taxa in collections (Fuentes et al. 2013; Zenni and Ziller 2011) and there is often inherent bias against collecting alien species. However, with the various sources of taxonomic uncertainty and changes to nomenclature, a physical record remains essential. Obtaining herbarium samples of flowering and fruiting trees can be logistically difficult (height and timing of flowering), but it is important for all alien taxa in a region to be catalogued. With changes in climate and nomenclature, and often substantial delays before the on-set of invasions, information on which trees are cultivated around the world is a vital background if the risks of future biological invasions are to be estimated

\section{What characteristics of a tree invasion need to be included in a standardized set of metrics?}

A standardized set of metrics for tree invasions has many possible advantages, but devising a list that would meet all requirements for all types of invasions is daunting [cf. McNaught et al. (2006)]. The metrics do, however, need to contain enough information such that they can be used to identify problems and prioritise action (cf. Red Lists in conservation science, Fig. 1). To achieve this, we consider that a set of metrics should provide information on status, abundance, spatial extent, and impact of an invasion and how these characteristics change through time. We argue that these characteristics of an invasion are necessary to: provide base-line statistics for biodiversity assessments; estimate impacts; estimate costs of different management strategies; estimate the threats posed; and ultimately place species into management and legislative categories as part of a strategic planning process. These characteristics are largely based on those used for conservation assessments (Mace et al. 2008), with the addition of a measure of impact. We reviewed published research on measuring each of these characteristics and propose six representative metrics (Table 1).

\section{Current and potential status}

The most basic measurement of status in invasion biology is whether a taxon is present outside its native range (Pysek et al. 2004). This is often the first information used for guiding biosecurity policy and management of alien invaders (Randall 2007). While 
Table 1 Key characteristics of an invasion, with the proposed standardized set of six basic metrics to allow for problem identification and the prioritisation of action (Fig. 1). Each proposed metric is denoted by a letter (a-f) as used in the main text

\begin{tabular}{|c|c|c|}
\hline Characteristic & Recommended metric(s) & Uses of metric(s) \\
\hline Current status & $\begin{array}{l}\text { (a) Category according to Blackburn et al. } \\
\text { (2011) (not yet translocated, translocated, } \\
\text { released into the wild, established self- } \\
\text { sustaining populations, or invasive) }\end{array}$ & $\begin{array}{l}\text { Placing species into } \\
\text { management and } \\
\text { legislative } \\
\text { categories } \\
\text { Providing headline } \\
\text { statistics for } \\
\text { biodiversity } \\
\text { assessment reports }\end{array}$ \\
\hline $\begin{array}{c}\text { Potential } \\
\text { status }\end{array}$ & $\begin{array}{l}\text { (b) Potential range size from a } \\
\text { species distribution model of } \\
\text { climatic suitability }\end{array}$ & $\begin{array}{l}\text { Conducting a risk } \\
\text { assessment } \\
\text { Prioritising species } \\
\text { for proactive } \\
\text { management }\end{array}$ \\
\hline
\end{tabular}

Abundance

(c) Number of invasion foci (populations)

(d) Compressed canopy area

(i.e. area of occupancy, AOO)

Population growth rate

(c) + (d) change in abundance over time

Extent

Spread

(e) change in extent over time

Impact (e) Area invaded (i.e. extent of occurrence, EOO) Either combined total if populations can be treated as separate OR alpha-hull of all locations

(6) 890

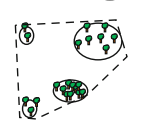

Defining the number of foci requiring management

Estimating management costs and current impacts

Planning control operations and determining management costs

Estimating management costs and current impacts.

Spatial planning of management efforts

Spatial prioritisation of management efforts

Conducting a risk assessment

Placing species into management and legislative categories

An evaluation in terms of economic, cultural, and biodiversity impacts

Additional metrics required for a more mechanistic understanding (Fig. 1)

Status split into habitats, counties, protected areas, grid cells, biome and ecoregion. Genetic diversity. Residence time. Origin. Number, extent, and value of cultivated individuals

Quantification of influence of barriers and mechanisms that could prevent a full invasion. Introduction-risk, species-based or area-based invasion debt quantified as appropriate, with estimate of how quickly it might be realized. Current and future pathways of introduction and dispersal identified and quantified

Number of individuals and stage/age structure of all invasion foci (populations), with information on reproductive output per individual. Size of seed-bank (if present)

Enough information to parameterize a suitable population growth rate model, e.g. a transition matrix, with some estimate of inter-annual and inter-site variation

Stage structure distribution of all individuals, seeds, and propagules

A time-series of area invaded (ha) over time. A dispersal model that combines a landscape explicit natural dispersal kernel with routes of human-mediated transport. Both coupled to map detailing likelihood of recruitment

Costs and benefits (in economic and social terms) split up into different stakeholder groups and spatially explicit. Differences between invaded and non-invaded sites in terms of native species richness, abundances and evenness, changes in soil properties, increased production costs, loss of revenue owing to lower productivity 
Table 1 continued

\begin{tabular}{llcl}
\hline Characteristic & Recommended metric(s) & Uses of metric(s) & $\begin{array}{l}\text { Additional metrics required for a more } \\
\text { mechanistic understanding (Fig. 1) }\end{array}$ \\
\hline Threat & $\begin{array}{l}\text { No specific metric proposed. A possible } \\
\text { method is to identify whether a species } \\
\text { might be a transformer or not (can use } \\
\text { observations recorded in the A-WRA), and } \\
\text { whether the species is likely to over-top the } \\
\text { recipient vegetation (Box 2) }\end{array}$ & $\begin{array}{c}\text { Conducting a risk } \\
\text { assessment } \\
\text { Prioritising species } \\
\text { for proactive } \\
\text { management }\end{array}$ & $\begin{array}{l}\text { Impact-based invasion debt quantified. } \\
\text { Projections of how costs and benefits will } \\
\text { change under different management } \\
\text { scenarios with estimated costs and } \\
\text { effectiveness to maintain current levels; to } \\
\text { contain for a specified duration; or to } \\
\text { eradicate. Global change scenarios } \\
\text { considered, as well as potential for } \\
\text { interactions with new introductions }\end{array}$ \\
& & & \\
& & &
\end{tabular}

such presence/absence lists are fraught with difficulties (see Box 1), invasive trees generally pose fewer problems than other groups in this respect-trees are often intentionally introduced for use as ornamentals or for (agro)forestry, most can be easily detected, and native ranges are often well studied. However, we recommend that a recent herbarium specimen be set as the minimum required level of evidence for presence in a region (Box 1). Such lists presuppose the biological species concept, whereas invasions arguably happen at the gene level (Petit 2004). Therefore, some indication of sub-specific identity is valuable. While such information can often be gleaned from herbarium records, molecular analyses can provide important additional insights, pin-pointing areas of origin, reducing taxonomic misclassifications, identifying hybridization, and identifying differences between native and alien populations (Zenni et al. 2014).

Beyond presence and absence, other metrics for status are intrinsically composite, requiring information on abundance and spread. Standardized levels of information have been proposed for the nested dichotomies of non-introduced and introduced; nonnaturalised and naturalised; and non-invasive and invasive species (Pyšek et al. 2004). Benchmark criteria (e.g. observed spread of more than $100 \mathrm{~m}$ within 50 years) has led to the development of a standardized invasive list for all trees and shrubs (Rejmánek and Richardson 2013; Richardson and Rejma'nek 2011). Based on these criteria we developed a list of questions to determine the status of a tree introduction in a given region (Supplementary Material 2). The answers to these questions allow for species to be characterised following Blackburn et al. (2011)'s unified framework for biological invasions (the most recent and comprehensive such scheme).

Predicting the potential status of a species at any particular place or time is problematic, though the basic criteria of invasiveness elsewhere and climatic suitability are good starting points (Hulme 2012). Estimates of potential status could also include an assessment of traits correlated to invasiveness and invasibility, and an assessment of the different mechanisms that might prevent an introduction becoming invasive (e.g. no suitable pollinator or dispersal agent). Developing a standard (and mathematically sound) metric for defining the probability that an invasion will result given particular condi-tions is a potentially valuable area of research (Leung et al. 2012).

One of the most basic limits to potential status is whether the region under consideration is climati-cally suitable or not. Species distribution models (SDMs) provide a good first estimate of potential distribution (Thuiller et al. 2005) and provide significant value for management, though the temp-tation to overstate the meaning of the quantitative results needs to be tempered by the various method-ological and theoretical limitations to the approach (Guisan et al. 2013; Nunez and Medley 2011). Consequently, we recommend using a climate-based SDM as a first approximation of whether naturaliza-tion might be limited by physiology, but fine-scaled distribution predictions linked to probability of occurrence models are likely to be more useful for on-ground management (Brummer et al. 2013; Kaplan et al. 2014; Rew et al. 2006). 
Abundance and population growth rate

At a broad scale, it is useful to estimate how many invasion foci there are, since the number of foci and their distribution have important implications for management. But while some invasions consist of distinct foci or populations, in many cases spatial distributions are more continuous. Based on reported tree pollen and seed dispersal distances (Petit and Hampe 2006), we suggest that foci separated by at least $10 \mathrm{~km}$ should have low levels of interaction and could safely be managed as distinct populations.

Conservation assessments, however, usually base abundance on the numbers of individuals and how this number changes with time. However, for tree species, individuals vary from seeds (which are small and numerous) to mature trees (which are large and much less numerous). As such there is a need to consider both numbers of individuals and the size and age (or ontogenetic) structure of populations. This is particularly relevant for species with large seed banks, where the size and longevity of seed-banks profoundly influence management decisions and outcomes (Panetta et al. 2011; Pieterse and Cairns 1988; Wilson et al. 2011). Size frequency histograms give some indication of likely population projections, but measurements of abundance, mortality, and fecundity over time are needed to calculate growth rate, while mechanistic and statistical models are needed to provide point estimates and rate predictions. Given the size and age structure of invasive tree populations, matrix models are well suited for deriving estimates population growth rates [e.g. Ardisia elliptica (Koop and Horvitz 2005), Gleditsia triacanthos (Marco and Paez 2000), Pinus nigra (Buckley et al. 2005), Prosopis spp. (Pichancourt et al. 2012), and Prunus serotina (Sebert-Cuvillier et al. 2007)]. There are a variety of approaches for such models, but a projection matrix with 3 or 4 stages (seeds; seedlings and/or saplings; reproductive adults) and corresponding transition probabilities (incorporating survival, growth, and reproduction), is a reasonable minimum for many situations, allowing estimates to be made of the finite rate of population increase $(\lambda)$ or population (or metapopulation) growth rate $[\mathrm{r}=$ $\ln (\lambda)$ ] (Caswell 2001).

For some species, individuals can be hard to tell apart, and it is often difficult to count all individuals. Therefore, abundance is more readily estimated from the invaded area (i.e. condensed area or the net area of infestation) (Hui et al. 2009). This, in essence, is a measure of extent - area of occupancy (AOO) at a fine spatial scale-but as a simple metric of relative abundance for invasive populations it provides a useful link to impact and management. One method of calculating $\mathrm{AOO}$ is to assess the percentage of area covered, $d$, in an area of size, $A$. The condensed area (100\% equivalent cover) is simply $A \times d / 100$. T h i s provides a measure of local abundance, especially in canopy-forming tree species. This measure offers the benefit of being easy to calculate from gridded data and/or digitally rectified aerial photography, without actually counting the number of individuals.

\section{Extent and spread}

Two measures have been adopted by the IUCN to describe the status of species' distributions (IUCN 2012) as they provide distinct, but equally valuable, information. First a raster-type approach can be used to describe the AOO for a particular unit (Gaston 2003) (e.g. quarter-degree grid or $\mathrm{km}^{2}$ cells) giving an estimation of the abundance and the capacity to spread locally (and in this case we take it to be a measure of abundance rather than extent). Second, vector-type approaches, e.g. convex-hulls, can be used to circumscribe observations, giving a measure of the extent of occurrence (EOO) (Gaston and Fuller 2009). An important consideration, however, is that surveys are never perfect. There are methods for describing uncertainty in distribution estimates due to imperfect detection (Mackenzie and Royle 2005), but a minimum requirement is to describe the area searched, when, and at what level of detail.

If monitored through time $\mathrm{AOO}$ and $\mathrm{EOO}$ can be converted into area or distance over time to estimate spread rate $(c)$, e.g. metres/year, $\mathrm{km} /$ year, or hectares/ year. However, the appropriate units might depend on the spatial arrangement of spread (e.g. radial increase in an uniform area, or linearly along a watercourse), and both the rate and type of spread might change depending on the stage of invasion (e.g. initially slow spread, followed by exponentially increasing spread). Population models that account for dispersal are increasingly used to estimate spread (Caplat et al. 2012b; Smolik et al. 2010), but the data requirements can be daunting. Where possible, a plot of a time series 
of EOO measurements would be a good minimum but, again, for many situations data are not available. Trends in herbarium records over time (Aikio et al. 2010), and increases in the number of records obtained from surveys (Robertson et al. 2010) are useful for within-area measures, but interregional comparisons are challenging.

Specific methods for estimating spread include using a grid overlaid on aerial photographs and other remote sensing images such as high-resolution satellite imagery or radar data (e.g. Lidar). The occupancy of invasive trees can then be estimated, and a time series of images with the same grid location allows calculation of change in occupancy and extent metrics (Visser et al. 2014). Similarly, presence/ absence transects can be repeated to obtain contingency tables including colonization and extinction rates. The colonization and extinction rates can be empirically modelled independently (Mackenzie and Royle 2005) or they can be fitted simultaneously along with the other two cases, cells remaining absent and cells remaining present (Jackson 2011), allowing estimates of spread rates. Simulations of this type allow managers to have a locally parameterized tool to test various management alternatives by simulating the effectiveness of different interventions over time and space (Caplat et al. 2014; Higgins et al. 2000). Several shortcut methods can also be useful for rapid estimation of spatio-temporal dynamics of invasive trees (Aslan et al. 2012). And an extremely useful aspect of trees is that various dating techniques (e.g. tree rings, morphometric measures, radio-carbon dating) can be used to age individuals in a populationhistorical extent can then be inferred from the spatial age structure allowing invasion reconstruction (Münz-bergova' et al. 2013; Richardson and Brown 1986). Finally, mechanistic approaches can be used, e.g. to predict seed movement across real landscapes based on prevailing wind patterns (Caplat et al. 2012b).

Impacts and threats posed

The impact of an invasive species has been defined as the product of extent, average abundance, and effect per unit or individual (Parker et al. 1999). As discussed above, while measuring abundance and extent is reasonably straightforward, it is much more difficult to quantify the effect per individual or unit
Despite many useful conceptual models, a detailed quantifi-cation of impact is often precluded by data require-ments, uncertainty, the non-linear nature of impacts, and the often complicated interactions between dif-ferent types of impacts. Moreover, the negative effects of many invasions are likely underappreciated [poorly studied, difficult to detect, or due to a delay between invasion and impact (Simberloff 2011)], whereas positive effects are frequently overlooked and remain controversial. Given the difficulties of measuring impact, we recommend that relevant qualitative data should be collated and quantified whenever possible. One method for doing this is the Australian Weeds Risk Assessment (A-WRA) protocol (Gordon et al. 2010). While many of the A-WRA questions are not relevant to impact, and the A-WRA was designed to be used pre-border, it is a useful and widely used standardized form. If the assessment is based on documented evidence it can provide a useful format for reviewing information relevant to impacts.

There could be substantial value in looking at how impact and threat are incorporated into risk assessments more systematically (Leung et al. 2012), and designing a scheme specifically for invasive trees. We propose that, for a baseline assessment for trees, two observations are used to determine threat-height in relation to native vegetation, and whether the species has a high risk of being a transformer [Box 2; Rejma 'nek et al. (2013)].

In short, the incorporation of standard metrics for impact and threat remains a major challenge. We believe that measures of effect per unit individual or area should be temporally and spatially explicit, and could be measured by cost (return or loss) on an area basis or for natural ecosystems by species extirpation per area over time. It would also be valuable to quantify how an introduced tree differs from cooccurring native species in key functional traits (e.g. water use, N-fixing, dominance) (Rundel et al. 2014), and estimate the benefits accrued against which any undesirable impacts can be evaluated (van Wilgen and Richardson 2014), though some components of impact and threat can be hard to quantify, e.g. the potential for hybridization with native species (Potts et al. 2003; Vanden-Broeck et al. 2012). The next step will be to develop networks of studies on impacts and, where 
Box 2 Categorizing invasion risk for trees

There are over 100 risk assessment models for invasive plant species (Leung et al. 2012), with some decision schemes developed specifically for trees or woody plants (Reichard and Hamilton 1997; Widrlechner et al. 2004). Any scheme investigating risk should, by definition, consider likelihoods and consequences. Here we discuss a simple way to allocate tree species to different categories of risk incorporating parts of the proposed standardized set of metrics

Likelihood of an invasion can be measured based on potential status on the invasion continuum and the likelihood of introduction or extent of planting. In the proposed set of metrics, climatic suitability is used as a coarse estimate of potential status, but this is in fact simply potential for naturalization. An estimation of potential status should also be informed by any a priori expectations that an invasion will occur, e.g. invasiveness elsewhere or the invasiveness of congeners. Invasiveness elsewhere is usually incorporated as a binary variable, but this is a true test of invasiveness only if the species has been introduced and had an opportunity to spread. Therefore invasiveness elsewhere can be expanded to include observations of the fate of introductions and the degree to which conditions where the known invasion occurred are similar to the conditions in the environment under consideration. More introductions to more regions, and a longer history and extent of planting should reduce the uncertainty as to whether a widespread invasion will occur (Wilson et al. 2011). A lack of invasions despite widespread planting forms the basis for proposed acceptable lists for horticulture (Dehnen-Schmutz 2011), and likewise repeated invasions in different biogeographic regions are indicative of a species that is highly likely to be invasive if introduced elsewhere. However, invasiveness elsewhere has little predictive power for those trees that have not been introduced or planted outside their native range (unless the original selection of species is correlated to invasive success, e.g. some types of forestry favour r-selected species). In the absence of information, the invasiveness of congeners can be used to estimate the a priori expectation of an invasion (Diez et al. 2012), as certain genera are over-represented in terms of invaders (Rejma'nek and Richardson 2013)

Here we consider one component of the many consequences of an invasion, the potential threat to communities and ecosystems. We recommend two simple measures for trees-expected invader height relative to the expected canopy height of native vegetation (i.e. would the invader likely over-top native vegetation), and whether a species can be defined as a transformer. For the latter we use the nine categories of transformer as defined by Richardson et al. (2000) — excessive users of resources; donors/ enhancers of limiting resources; fire promoters/suppressors; sand stabilizers; erosion promoters; colonizers of intertidal mudflats; litter accumulators; soil carbon storage modifiers; and salt accumulators. Transformer species have the potential to significantly affect ecosystem functioning and thereby services

The proposed analysis will not require much work in addition to the proposed metrics, as most pertinent information is included in the Australian Weeds Risk Assessment. But if the mechanisms underlying invasion and impact are understood, or if there are robust correlations with particular traits, then a more precise risk assessment, and more specific management recommendations, can be produced

Box 2 Figure 1 A proposed system for rapidly assessing the threat posed by an introduced tree. Darker shades indicate higher threat

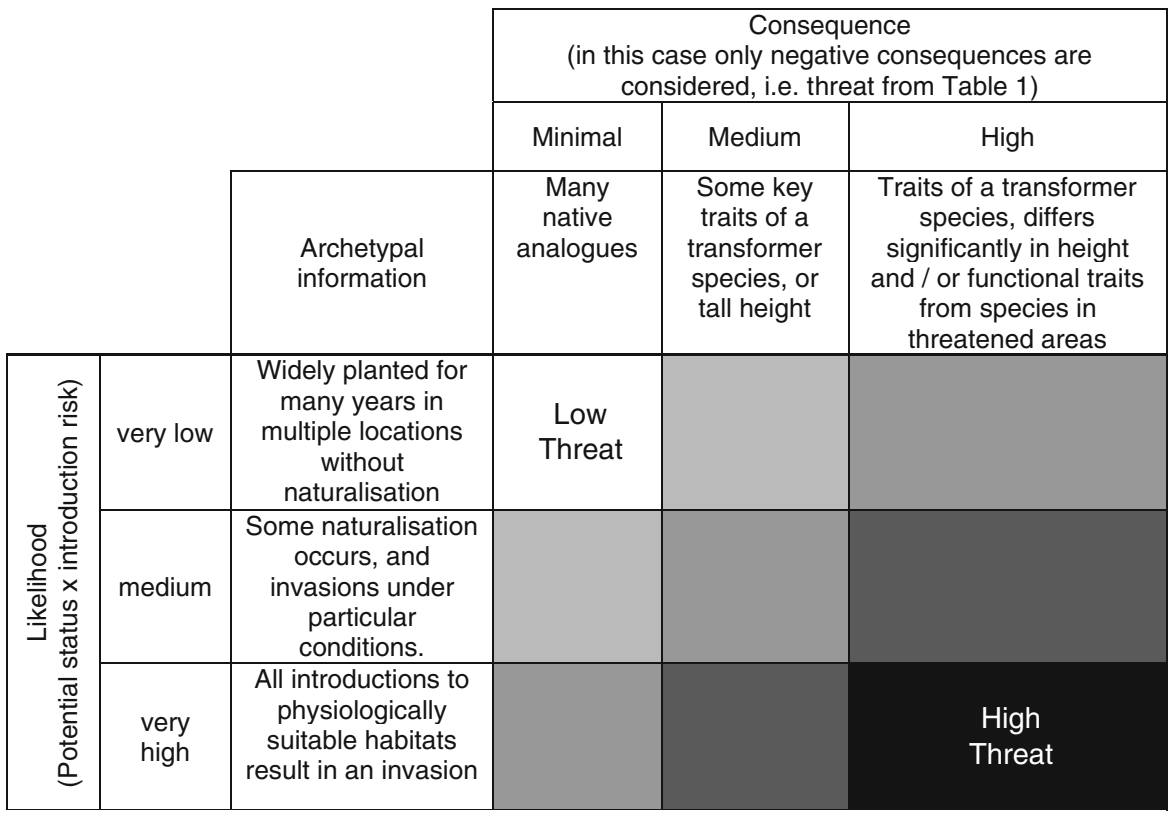


possible, monitoring schemes should be modified to obtain information on the dynamics of the invader and the dynamics of the invaded community (both native dominants and species of concern).

\section{Integrating metrics}

There is substantial value in integrating these six metrics to improve our insight and management of invasive species. We discuss two possibilities herefirst combining current and potential status with impact and threat can provide insights for risk assessment (Box 2); and second abundance, population growth rate, extent and spread are all related and if jointly considered will provide insights into invasion dynamics (Box 3).

\section{A standard report}

Using the recommendations above, we compiled information on a couple of notable invasions and present a standardized template for reporting tree invasions ("Appendices 1 and 2'"). Of notable interest is how the methods used to estimate the metrics vary, and how each carries particular levels of uncertainty.

\section{Discussion}

While lists of invasive species are extremely valuable (Rejma'nek and Richardson 2013), indices are needed that can be used by decision makers and managers to estimate the state of invasions globally and how this will change through time (McGeoch et al. 2010). For invasive trees, we recommend as a minimum: (a) the current status of a species in a given region as defined by Blackburn's scheme (with regions ideally defined based on biogeography); (b) the potential status of the species (using modelling to estimate climate suitability); (c) the number of management foci (which should correspond to the number of populations); (d) the condensed canopy cover (AOO at a very fine spatial scale); (e) the EOO for each management foci/ population or the invasion as a whole; and (f) qualitative estimates of the impacts and threats posed (with information structured along the lines of the Australian Weed Risk Assessment Protocol). The methods for collecting these basic metrics are available although costly to obtain in some instances. More information will be required to answer specific question [e.g. estimates of the cost of eradication will require estimates of the detectability of individuals (Panetta et al. 2011); see also Table 1], and our proposal also does not include important aspects that are required for strategic planning [e.g. future population growth rates and spread rates (though a time series of $\mathrm{AOO}$ and $\mathrm{EOO}$ can be used to estimate past rates)].

There are several ways in which this set of six metrics could be expanded to incorporate other characteristics of an invasion, e.g. species-level traits, introduction dynamics, and traits of the recipient environment. There is an extensive and long-established literature on how intrinsic and extrinsic traits are correlated to the success of invasions and so can have value for risk assessments (Caplat et al. 2012a; Hui et al. 2011; Hui et al. 2014; Williamson and Fitter 1996). Species traits can also directly affect the utility of particular metrics. For example, for trees there is often very high seedling and sapling mortality but extended adult longevity, so simple measures of total numbers of individuals can be misleading both in terms of predicting population trends and for management. Seed bank longevity, age at maturity, generation time, and life span all provide important context and need to be estimated if the population dynamics are to be fully explored (Horvitz 2011; Petit and Hampe 2006; Rejmanek 2011).

Invasion dynamics are strongly influenced by the size, location, and number of introduction foci, i.e. the introduction dynamics (Wilson et al. 2009). The extent, spatial arrangement, and residence time of plantings will also affect the likelihood of an invasion being realized (Caplat et al. 2014). Moreover, if an invasion is realized, substantial conflicts can result between utilization and negative impacts affecting the management options available. As such, the history of introduction and current cultivated status provide important background information both for predicting the rate of an invasion, and for devising management strategies (van Wilgen et al. 2011).

We recognise that there are many further measures that could be added to an expanded list of metrics. However, it is important for managing invasions to have a mechanism that provides rapid assessments of 
Box 3 Using the spatial structure of an invasion to provide management recommendations

Spread rate, abundance, and extent if considered jointly can provide important information for prioritising when, where, and how much management effort is required. They also provide vital information that can be used to classify invasive species. One approach for evaluating naturalized trees that included elements of spread rate, abundance, and extent was developed in Puerto Rico $[1=$ Slow spread and infrequent reproduction, $2=$ Slow spread and abundant reproduction, $3=$ Rapid spread and infrequent reproduction, $4=$ Rapid spread and abundant reproduction; $\mathrm{A}=$ Abundant, $\mathrm{C}=$ Common, $\mathrm{I}=$ Infrequent or confined to limited habitats less than 100 hectares, $\mathrm{R}=$ Rare; (Francis and Liogier 1991)]. In outline it is similar to Rabinowitz's (1981) scheme for classifying different types of rarity. However, while both schemes provides useful approaches for thinking about and categorising invasions, they are less useful as management tools as the categories are binary and so the cut-offs are arbitrary and most species are likely to be close to the cut-off points. Moreover, at least for an extension of Rabinowitz's scheme, during the course of an invasion we expect species to change position, in part as a result of their introduction histories (Wilson et al. 2009; Wilson et al. 2007)

Box 3 Table 1 Invasive tree species based on an adaptation of Rabinowitz's (1981) scheme for classifying rare species

\begin{tabular}{|c|c|c|c|c|c|}
\hline & \multirow[b]{3}{*}{$\begin{array}{l}\text { Habitat } \\
\text { Specificity }^{2}\end{array}$} & \multicolumn{4}{|c|}{${\text { Extent of occurrence }(E O O)^{1}}^{1}$} \\
\hline & & \multicolumn{2}{|c|}{ Wide } & \multicolumn{2}{|c|}{ Narrow } \\
\hline & & Broad & Restricted & Broad & Restricted \\
\hline \multirow{2}{*}{$\begin{array}{l}\text { Fine-scale } \\
\text { area of } \\
\text { occupancy } \\
(\mathrm{AOO})^{3}\end{array}$} & Large & $\begin{array}{c}\text { Acacia dealbata } \\
\text { (Chile) }\end{array}$ & $\begin{array}{l}\text { Salix spp. } \\
\text { (Argentina) }\end{array}$ & $\begin{array}{l}\text { Hovenia dulcis } \\
\text { (Brazil) }\end{array}$ & $\begin{array}{c}\text { Melaleuca } \\
\text { quinquenervia } \\
\text { (SE USA) }\end{array}$ \\
\hline & Small & $\begin{array}{c}\text { Paraserianthes } \\
\text { lophantha } \\
\text { (South Africa) }\end{array}$ & $\begin{array}{c}\text { Ficus carica } \\
\text { (California, USA) }\end{array}$ & $\begin{array}{c}\text { Araucaria } \\
\text { araucana } \\
(\mathrm{UK})\end{array}$ & $\begin{array}{c}\text { Unlikely to be } \\
\text { considered } \\
\text { invasive }\end{array}$ \\
\hline
\end{tabular}

${ }^{1}$ Wide EOO would be $>1000000 \mathrm{~km}^{2}$; or $>50 \%$ of land area on an island; whereas narrow would be $<100000$ $\mathrm{km}^{2}$; or $<10 \%$ of land area on an island (with 'average' distributions somewhere in between)

${ }^{2} \mathrm{~A}$ broad habitat specificity would be three or more vegetation types; whereas restricted would be confined to a single patchy soil type, e.g. serpentine soil in Europe, or a single vegetation type.

${ }^{3}$ The fine scale area of occupancy is essentially a measure of population abundance for trees - either number of individuals per unit area or condensed canopy cover.

Another approach is to explicitly recognize that the patterns and processes underlying biological invasions change depending on the spatial scale investigated (Pauchard and Shea 2006). For example, scale-area curves have been used to estimate overall rates of growth and spread for species of conservation concern (Wilson et al. 2004), to determine the scale and trajectory of an invasion (Donaldson et al. 2014; Veldtman et al. 2010), and, in the context of native range dynamics, to predict invasiveness (Hui et al. 2011; Hui et al. 2014). Because of the complex nature of scale-area curves, a simple assessment of spatial pattern can be performed by combining area of occupancy (AOO) and extent of occurrence (EOO). The ratio of AOO to EOO gives a snapshot of the spatial aggregation of a species that is easy to calculate if gridded data of presence exists. Over time, an increase in AOO is likely to indicate an increase in canopy cover or abundance within a specific area, while an increase in EOO reflects range expansion. Managing a species that exhibits a temporal change in its distribution depends on whether there is a change in one or both or AOO and EOO

the threat posed by an introduced species (Box 2). One could use a combination of key traits [e.g. the z-score proposed for conifers (Richardson and Rejma 'nek 2004)], together with an understanding of landscape features (e.g. habitat suitability; wind speed), and the nature of the introduction event [e.g. a lone tree as a point source vs. a plantation, fencerow or wind break
(Zenni in press)]. We suspect that ensuring that the metrics used to describe an invasion can be linked to traits and mechanisms will be a fruitful area of research, particularly when novel environments are likely to reshuffle existing communities and provide more opportunities for invasions to occur (Williams and Jackson 2007). 
Box 3 continued

Box 3 Figure 1 Plotting area of occupancy against extent of occurrence can provide useful insights into relative invasion dynamics. By definition AOO cannot be higher than EOO (grey area)

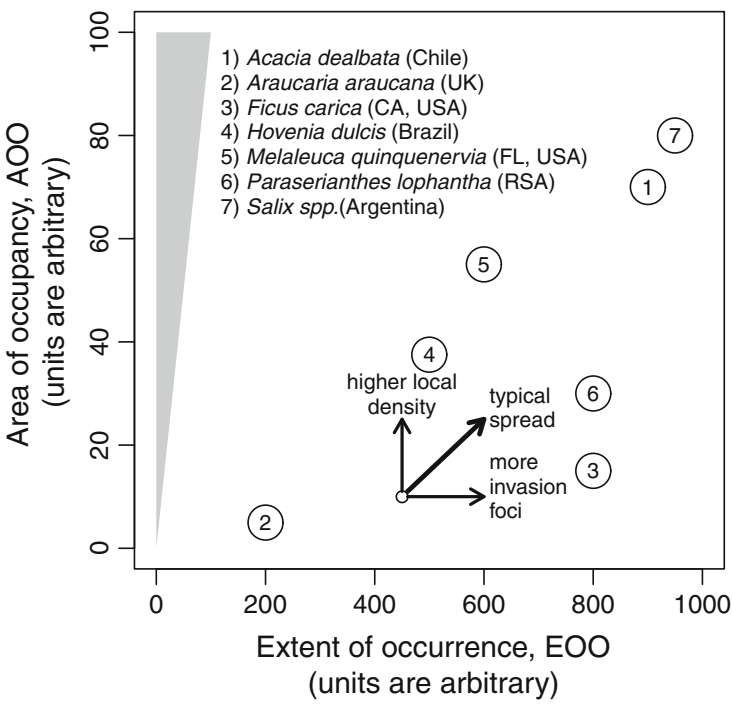

An invasion with a few large monocultural stands will have an AOO:EOO ratio close to 1, whereas a species with large extent but low occupancy (i.e. many small invasion foci) will have an AOO:EOO closer to 0. In these cases the first could represent a species with substantial local impact, but where containment to a few areas might be feasible, in the second case the species could be planted widely but has not spread much locally (e.g. a new popular ornamental introduction)

Trajectories in time can inform on the spatial dynamics of a species: spread by diffusion would result in a constant AOO:EOO ratio; while the formation of new invasion foci through long-distance dispersal would initially only increase EOO. If containment were successful, EOO should not increase, local clearing will initially reduce AOO, but EOO will only show a lasting decline if populations (including seed-banks) are extirpated

However, in some specific cases, scale-area curves or measurements of the AOO:EOO may underestimate invasions if there are no clear procedures to scale up or down. For instance, trees restricted to riparian corridors or strandlines will, by nature of the arrangement of suitable habitat, have constraints on their scale-area curves. Comparing range patterns between invasions is likely to be a substantial challenge and opportunity for invasion biology, and such patterns should be reported. For cross-scale management, see Caplat et al. (2014), and Kaplan et al. (2014)

\section{Conclusions}

Tree invasions are causing important ecological and social impacts, but no consensus has been reached on how to measure and monitor them at regional and national scales. We hope this paper will stimulate discussion not just on how to quantify tree invasions, but also focus attention on selecting the best and most practical variables and methods for estimating metrics, quantifying their uncertainty, and determining how these metrics should help guide policy and management. Our proposed set of metrics will facilitate this complex task, especially for invasions that cross administrative boundaries. These metrics provide the basis for assessing the success and failures of current management efforts and may help to improve future initiatives, particularly as it is expected that shifts in native species distributions in response to climate change will be analogous to invasions (Caplat et al. 2013). It remains to be seen whether each major functional or taxonomic group would need a new suite of metrics, but clearly extent is less easily measured for organisms that are more mobile as adults: interannual population fluctuations (and temporal invasion windows) might be important concepts that need to be captured. Whether a useful standardized set of metrics is achievable even for a single group like trees remains to be seen, but we feel that research in this area has the potential to advance the discipline as much as the processes of developing Red Lists has forced conservation science to develop a sound scientific base (Mace et al. 2008). The next step will be to trial the 
standardized set of metrics, revise the metrics in the light of practical experience, and develop practical guidelines for their measurement and reporting.

Acknowledgments This paper resulted from the workshop "Tree invasions-patterns \& processes, challenges \& opportunities" held in Bariloche, Argentina in 2012. We thank all participants at the meeting for valuable discussion. Daniel Simberloff and three reviewers provided valuable comments that improved the manuscript. JRUW acknowledges funding from the South African Working for Water Programme of the Department of Environmental Affairs. IAD was supported by Core funding for Crown Research Institutes from the New Zealand Ministry of Business, Innovation and Employment's Science and Innovation Group. AP is funded by Ministry of Economy, ICM P05-002 and Conicyt, PFB-23. DMR acknowledges support from the National Research Foundation (Grant 85417), the DST-NRF Centre of Excellence (partly though the collaborative project with the Working for Water programme on "Research for Integrated Management of Invasive Alien Species") and the Oppenheimer Memorial Trust. CH was supported by the CPRR 81825 of the NRF. BDM was supported by NSF- WildFIRE PIRE, OISE 09667472. BLW was supported by the CSIRO Climate Adaptation Flagship. RDZ was supported by CNPq-Brazil and The University of Tennessee.

\section{Appendix 1: Example of species report (Acacia paradoxa DC. in South Africa)}

Species: Acacia paradoxa DC. example herbarium record: (Slater 7035, BOL). No subspecific information available.

Location: South Africa.

Status: Invasive; D2 under Blackburn; (in cultivation?): not known to be cultivated recently (possibly introduced for ornamentation 100 years ago).

Potential: $6-13 \%$ of South African land area; 70-160 M ha (Zenni et al. 2009; Moore et al. 2011).

Abundance: $\sim 12,000$ plants (2010); 0.7 ha (condensed area); 70,000-700,000 seeds (2010).

Population Growth Rate: Few large individuals, $60-80 \%$ of population $<1 \mathrm{~m}$ and not reproductive in 2009; only 50 individuals $>3 \mathrm{~m}$.

Extent: 1 population; 350 ha (condensed polygon) in terms of uncertainty, a range of values of 155-1,550 ha was used in one modelling exercise (Moore et al. 2011).

Spread: natural radial increase of $100 \mathrm{~m} \mathrm{year}^{-1}$ (assumed value), mostly gravity. Potential for seeds to be transported by road vehicles (not realized as yet).

Impact: Monoculture created; nuisance thorns. Impact ZAR 1,701 year ${ }^{-1} \mathrm{ha}^{-1}$ (uncondensed area, monetary values from 2000) extrapolated from (de Wit et al. 2001). For a completed Australian Weed Risk Assessment see Zenni et al. (2009).

Threat: If potential area is multiplied by impact get to ZAR 100 billion year $^{-1}$.

Survey method(s) used: Systematic walked transects over $\sim 700$ ha to generate point distributions. At a national scale this distinctive species has been included in general field-guides for invasive plants for many years, and dedicated leaflets asking for sightings have been distributed nationally since 2009. Any records should also have been picked up by the substantial on-going research, surveillance, and management into Australian acacias in South Africa.

Notes: eradication plan in place.

Contact: invasivespecies@ sanbi.org.za.

Information compiled by: John Wilson, jrwilson@sun.ac.za.

Refs:

de Wit MP, Crookes DJ and van Wilgen BW (2001) Conflicts of interest in environmental management: estimating the costs and benefits of a tree invasion. Biological Invasions 3: 167-178.

Moore JL, Runge MC, Webber BL and Wilson JRU (2011) Contain or eradicate? Optimizing the management goal for Australian acacia invasions in the face of uncertainty. Diversity and Distributions 17: 1047-1059.

Zenni et al. (2009) Evaluating the invasiveness of Acacia paradoxa in South Africa. South African Journal of Botany 75: 485-496.

\section{Appendix 2: Example of species report (Pinus contorta Loundon. in New Zealand)}

Species: Pinus contorta Loudon.

Pinus contorta Loudon subsp. contorta $=$ Pinus contorta Loudon var. contorta.

Pinus contorta Loudon var. contorta.

Pinus contorta subsp. latifolia $=$ Pinus contorta var. latifolia Engelm. ex S.Watson.

Pinus contorta var. latifolia Engelm. ex S.Watson.

Location: New Zealand (numerous locations).

Status: Invasive; E under Blackburn; All four subspecies of lodgepole pine (contorta, bolanderi, latifolia and murrayana) have been planted (Miller and Ecroyd, 1987) and all regenerate naturally. (Ledgard 2001) (in cultivation?): Not known to be cultivated recently. Introduced in 1880 and established widely for erosion control during 1960s and 70s on a 
few thousand hectares and self-sustaining since then (Miller and Ecroyd 1987, Ledgard 2001). Suggested as possible covering $\sim 100,000$ ha by late 1990s (Ledgard 2001).

Potential: all already invasive. 10-15\% of New Zealand land area (i.e. $>2.5 \mathrm{M}$ ha) suitable although could be greater.

Abundance: Various density stands. Seeds freely to high elevation and cones relatively young.

Population growth rate: Published information on estimated extent of cover (Miller and Ecroyd 1987, Ledgard 2001) suggests extent may be increasing at between 5 and $8 \%$ per annum despite control efforts.

Extent: Numerous populations (many large and $>1,000$ hectares) totalling $>100,000$ ha extent at all densities. Many populations are found in remote locations as a legacy of where their establishment attempted to protect erosion-prone land from massmovement. Due to their remoteness and potential cost there is little incentive address control or removal.

Spread: Natural radial increase of $\sim 5,000$ ha year $^{-1}$ (assumed value), mostly wind and gravity.

Impact: Major visual transformation of iconic grazed grasslands into forest, with consequent recreational value loss and aesthetic impact. Invasions most problematic in low-stature native vegetation (Froude 2011), with up to $100 \%$ loss of native plant biodiversity from high elevation grasslands (Ledgard \& Paul 2008), strong shifts in fungal communities (Dickie et al. 2010) and, based on results from Pinus nigra strong effects on soil invertebrate diversity even at low tree-densities (Dickie et al. 2011). Economic loss through reduction in land for low-intensity grazing (sheep, beef-cattle). Loss of water a serious concern in some areas (Fahey \& Jackson 1997).

Threat: Highest threat is in conservation grasslands and alpine zone where removal will have high non-target impacts.

Survey method(s) used: No national objective survey or monitoring. One province (Canterbury Regional Council) has systematic estimates of extent of cover and density in 11 representative catchments $\sim 70,000$ ha to generate point and polygon distributions. Department of Conservation records the presence of weed species in a $10 \times 10 \mathrm{~km}$ grid.

Notes: Limited control in a few locations.

Contact: Ian Dickie, ian.dickie@lincoln.ac.za.

Information compiled by: Larry Burrows, burrows1@landcareresearch.co.nz.

\section{Refs:}

Benecke, U. 1967: The weed potential of lodgepole pine. Tussock Grasslands and Mountain Lands Institute Review 13: 36-43.

Dickie IA, Bolstridge N, Cooper JA, Peltzer DA 2010. Co-invasion by Pinus and its mycorrhizal fungi. New Phytologist 187: 475-484.

Dickie IA, Yeates GW, St John MG, Stevenson BA, Scott JT, Rillig MC, Peltzer DA, Orwin KH, Kirschbaum MUF, Hunt JE, Burrows LE, Barbour MM, Aislabie J 2011. Ecosystem service and biodiversity trade-offs in two woody successions. Journal of Applied Ecology 48: 926-934.

Fahey B, Jackson R 1997. Hydrological impacts of converting native forests and grasslands to pine plantations, South Island, New Zealand. Agricultural and Forest Meteorology 84:69-82.

Ledgard, N. 2001: The spread of lodgepole pine (Pinus contorta, Dougl.) in New Zealand. Forest Ecology and Management 141:43-57.

Ledgard NJ, Paul TSH 2008. Vegetation successions over 30 years of high country grassland invasion by Pinus contorta. New Zealand Plant Protection 61: 98-104.

\section{References}

Aikio S, Duncan RP, Hulme PE (2010) Herbarium records identify the role of long-distance spread in the spatial distribution of alien plants in New Zealand. J Biogeogr 37:1740-1751

Aslan CE, Rejmanek M, Klinger R (2012) Combining efficient methods to detect spread of woody invaders in urban-rural matrix landscapes: an exploration using two species of Oleaceae. J Appl Ecol 49:331-338

Bean AR (2007) A new system for determining which plant species are indigenous in Australia. Aust Syst Bot 20:1-43

Blackburn TM, Pyšek P, Bacher S, Carlton JT, Duncan RP, Jarošík V, Wilson JRU, Richardson DM (2011) A proposed unified framework for biological invasions. Trends Ecol Evol 26:333-339

Brummer TJ, Maxwell BD, Higgs MD, Rew LJ (2013) Implementing and interpreting local-scale invasive species distribution models. Divers Distrib 19:919-932

Buckley YM, Brockerhoff E, Langer L, Ledgard N, North H, Rees M (2005) Slowing down a pine invasion despite uncertainty in demography and dispersal. J Appl Ecol 42:1020-1030

Caplat P, Cheptou P-O, Diez J, Guisan A, Larson B, MacDougall A, Peltzer D, Richardson DM, Shea K, van Kleunen M, Zhang R, Buckley YM (2013) Movement, impacts and management of plant distributions in response to climate change: insights from invasions. Oikos 122:1265-1274 
Caplat P, Coutts S, Buckley YM (2012a) Modeling population dynamics, landscape structure, and management decisions for controlling the spread of invasive plants. In: Ostfeld RS, Schlesinger WH (eds) Year in Ecology and Conservation Biology, Annals of the New York Academy of Sciences, pp 72-83. doi:10.1111/j.1749-6632.2011.06313.x

Caplat P, Nathan R, Buckley YM (2012b) Seed terminal velocity, wind turbulence, and demography drive the spread of an invasive tree in an analytical model. Ecology 93:368-377

Caplat P, Hui C, Maxwell B, Peltzer D (2014) Cross-scale management strategies for optimal control of trees invading from source plantations. Biol Invasions 16. doi:10. 1007/s10530-013-0608-7

Caswell H (2001) Matrix population models: construction, analysis and interpretation. Sinauer Associates Inc., Sunderland

Dehnen-Schmutz K (2011) Determining non-invasiveness in ornamental plants to build green lists. J Appl Ecol 48:1374-1380

Diez JM, Hulme PE, Duncan RP (2012) Using prior information to build probabilistic invasive species risk assessments. Biol Invasions 14:681-691

Donaldson JS, Richardson DM and Wilson JRU (2014) Scalearea curves identify artefacts of human use in the spatial structure of an invasive tree. Biol Invasions 16. doi:10. 1007/s10530-013-0602-0

Francis JK, Liogier HA (1991) Naturalized exotic tree species in Puerto Rico. USDA Forest Service General Technical Report SO-82

Fuentes N, Pauchard A, Sanchez P, Esquivel J, Marticorena A (2013) A new comprehensive database of alien plant species in Chile based on herbarium records. Biol Invasions 15:847-858

Gaston KJ (2003) The structure and dynamics of geographic ranges. Oxford University Press, Oxford, p 266

Gaston KJ, Fuller RA (2009) The sizes of species' geographic ranges. J Appl Ecol 46:1-9

Gordon DR, Mitterdorfer B, Pheloung PC, Ansari S, Buddenhagen $\mathrm{C}$, Chimera C, Daehler CC, Dawson W, Denslow JS, LaRosa A, Nishidal T, Onderdonk DA, Panetta FD, Pyšek P, Randall RP, Richardson DM, Tshidada NJ, Virtue JG, Williams PA (2010) Guidance for addressing the Australian Weed Risk Assessment questions. Plant Prot Q 25:56-74

Guisan A, Tingley R, Baumgartner JB, Naujokaitis-Lewis I, Sutcliffe PR, Tulloch AIT, Regan TJ, Brotons L, McDonald-Madden E, Mantyka-Pringle C, Martin TG, Rhodes JR, Maggini R, Setterfield SA, Elith J, Schwartz MW, Wintle BA, Broennimann O, Austin M, Ferrier S, Kearney MP, Possingham HP, Buckley YM (2013) Predicting species distributions for conservation decisions. Ecology Letters 16:1424-1435

Gundale MJ, Pauchard A, Langdon B, Peltzer DA, Maxwell BD, Nuñez MA (2014) Can model species be used to advance the field of invasion ecology? Biol Invasions 16. doi:10. 1007/s10530-013-0610-0

Guo Q (2011) Counting “exotics". Neobiota 9:71-73

Gurevitch J, Fox GA, Wardle GM, Inderjit, Taub D (2011) Emergent insights from the synthesis of conceptual frameworks for biological invasions. Ecology Letters 14(4): 407-418

Higgins SI, Richardson DM, Cowling RM (2000) Using a dynamic landscape model for planning the management of alien plant invasions. Ecol Appl 10:1833-1848

Horvitz CC (2011) Demography. In: Simberloff D, Rejmánek M (eds) Encyclopedia of biological invasions. University of California Press, Berkeley and Los Angeles, pp 147-150

Hui C, McGeoch MA, Reyers B, le Roux PC, Greve M, Chown SL (2009) Extrapolating population size from the occupancy-abundance relationship and the scaling pattern of occupancy. Ecol Appl 19:2038-2048

Hui C, Richardson DM, Robertson MP, Wilson JRU, Yates CY (2011) Macroecology meets invasion ecology: linking native distribution of Australian acacias to invasiveness. Divers Distrib 17:872-883

Hui C, Richardson DM, Visser V and Wilson JRU (2014) Macroecology meets invasion ecology: performance of Australian acacias and eucalypts around the world foretold by features of their native ranges. Biol Invasions 16. doi:10. 1007/s10530-013-0599-4

Hulme PE (2003) Biological invasions: winning the science battles but losing the conservation war? Oryx 37:178-193

Hulme PE (2012) Weed risk assessment: a way forward or a waste of time? J Appl Ecol 49:10-19

Ibáñez I, Diez JM, Miller LP, Olden JD, Sorte CJB, Blumenthal DM, Bradley BA, D'Antonio CM, Dukes JS, Early RI, Grosholz ED, Lawler JJ (in press) Integrated assessment of biological invasions. Ecological Appl. doi:10.1890/13-0776.1

IUCN (2012) IUCN red list categories and criteria version 3.1. Gland, Switzerland

Jackson CH (2011) Multi-state models for panel data: the msm package for R. J Stat Softw 38:1-28

Kaplan H, van Niekerk A, Le Roux JJ, Richardson DM, Wilson JRU (2014) Incorporating risk mapping at multiple spatial scales into eradication management plans. Biol Invasions 16. doi:10.1007/s10530-013-0611-z

Koop AL, Horvitz CC (2005) Projection matrix analysis of the demography of an invasive, nonnative shrub (Ardisia elliptica). Ecology 86:2661-2672

Leung B, Roura-Pascual N, Bacher S, Heikkilä J, Brotons L, Burgman MA, Dehnen-Schmutz K, Essl F, Hulme PE, Richardson DM, Sol D, Vilà M (2012) TEASIng apart alien species risk assessments: a framework for best practices. Ecol Lett 15:1475-1493

Lowe S, Browne M, Boudjelas S, De Poorter M (2000) 100 of the world's worst invasive alien apecies a selection from the Global Invasive Species Database. Invasive Species Specialist Group (ISSG), World Conservation Union (IUCN), $12 \mathrm{pp}$

Mace GM, Collar NJ, Gaston KJ, Hilton-Taylor C, Akcakaya HR, Leader-Williams N, Milner-Gulland EJ, Stuart SN (2008) Quantification of extinction risk: IUCN's System for classifying threatened species. Conserv Biol 22:1424-1442

Mackenzie DI, Royle JA (2005) Designing occupancy studies: general advice and allocating survey effort. J Appl Ecol 42:1105-1114

Marco DE, Paez SA (2000) Invasion of Gleditsia triacanthos in Lithraea ternifolia Montane forests of central Argentina. Environ Manage 26:409-419 
Martin N, Paynter Q (2010) Assessing the biosecurity risk from pathogens and herbivores to indigenous plants: lessons from weed biological control. Biol Invasions 12:3237-3248

McGeoch MA, Butchart SHM, Spear D, Marais E, Kleynhans EJ, Symes A, Chanson J, Hoffmann M (2010) Global indicators of biological invasion: species numbers, biodiversity impact and policy responses. Divers Distrib 16:95-108

McGeoch MA, Spear D, Kleynhans EJ, Marais E (2012) Uncertainty in invasive alien species listing. Ecol Appl 22:959-971

McNaught I, Thackway R, Brown L, Parsons M (2006) A field manual for surveying and mapping nationally significant weeds. Bureau of Rural Sciences, Canberra

Münzbergová Z, Hadincová V, Wild J and Kindlmannová J (2013) Variability in the contribution of different life stages to population growth as a key factor in the invasion success of Pinus strobus. PLoS ONE 8

Nuñez MA, Medley KA (2011) Pine invasions: climate predicts invasion success; something else predicts failure. Divers Distrib 17:703-713

Nuñez MA, Pauchard A (2010) Biological invasions in developing and developed countries: does one model fit all? Biol Invasions 12:707-714

Panetta FD, Csurhes S, Markula A, Hannan-Jones M (2011) Predicting the cost of eradication for 41 Class 1 declared weeds in Queensland. Plant Prot Q 26:42-46

Parker IM, Simberloff D, Lonsdale WM, Goodell K, Wonham M, Kareiva PM, Williamson MH, Holle BV, Moyle PB, Byers JE, Goldwasser L (1999) Impact: toward a framework for understanding the ecological effects of invaders. Biol Invasions 1:3-19

Pauchard A, Shea K (2006) Integrating the study of non-native plant invasions across spatial scales. Biol Invasions 8:399-413

Pereira HM, Ferrier S, Walters M, Geller GN, Jongman RHG, Scholes RJ, Bruford MW, Brummitt N, Butchart SHM, Cardoso AC, Coops NC, Dulloo E, Faith DP, Freyhof J, Gregory RD, Heip C, Hoft R, Hurtt G, Jetz W, Karp DS, McGeoch MA, Obura D, Onoda Y, Pettorelli N, Reyers B, Sayre R, Scharlemann JPW, Stuart SN, Turak E, Walpole M, Wegmann M (2013) Essential biodiversity variables. Science 339:277-278

Petit RJ (2004) Biological invasions at the gene level. Divers Distrib 10:159-165

Petit RJ, Hampe A (2006) Some evolutionary consequences of being a tree. Annual review of ecology evolution and systematics, p 187-214

Piazza A (2010) About optimal harvesting policies for a multiple species forest without discounting. J Econ 100:217-233

Pichancourt JB, Chades I, Firn J, van Klinken RD, Martin TG (2012) Simple rules to contain an invasive species with a complex life cycle and high dispersal capacity. J Appl Ecol 49:52-62

Pieterse PJ, Cairns ALP (1988) Factors affecting the reproductive success of Acacia longifolia (Andr) Willd. in the Banhoek Valley, South-western Cape, Republic of South Africa. South African J Botany 54:461-464

Potts BM, Barbour RC, Hingston AB, Vaillancourt RE (2003) Genetic pollution of native eucalypt gene pools-identifying the risks. Aust J Bot 51:1-25
Pyšek P, Danihelka J, Sádlo J, Chrtek J, Chytrý M, Jarošík V, Kaplan Z, Krahulec F, Moravcová L, Pergl J, Štajerová K, Tichý L (2012) Catalogue of alien plants of the Czech Republic (2nd edition): checklist update, taxonomic diversity and invasion patterns. Preslia 84:155-255

Pyšek P, Richardson DM, Pergl J, Jarošík V, Sixtová Z, Weber E (2008) Geographical and taxonomic biases in invasion ecology. Trends Ecol Evol 23:237-244

Pyšek P, Richardson DM, Rejmánek M, Webster GL, Williamson M, Kirschner J (2004) Alien plants in checklists and floras: towards better communication between taxonomists and ecologists. Taxon 53:131-143

Rabinowitz D (1981) Seven forms of rarity. In: Synge H (ed) Aspects of rare plant conservation. Wiley, Chichester, pp 205-217

Randall RP (2007) The introduced flora of Australia and its weed status. CRC for Australian Weed Management, Adelaide

Reichard SH, Hamilton CW (1997) Predicting invasions of woody plants introduced into North America. Conserv Biol 11:193-203

Rejmánek M (2011) Invasiveness. In: Simberloff D, Rejmánek M (eds) Encyclopedia of biological invasions. University of California Press, Berkeley and Los Angeles, pp 379-385

Rejmánek M, Richardson DM (2013) Trees and shrubs as invasive alien species-2013 update of the global database. Divers Distrib 19:1093-1094

Rejmánek M, Richardson DM, Pyšek P (2013) Chapter 13: Plant invasions and invasibility of plant communities. In: van der Maarel E, Franklin J (eds) Vegetation ecology, vol 2. Wiley, New york, pp 387-424

Rew LJ, Lehnhoff EA, Maxwell BD (2007) Non-indigenous species management using a population prioritization framework. Can J Plant Sci 87:1029-1036

Rew LJ, Maxwell BD, Dougher FL, Aspinall R (2006) Searching for a needle in a haystack: evaluating survey methods for non-indigenous plant species. Biol Invasions 8:523-539

Richardson DM, Brown PJ (1986) Invasion of mesic mountain fynbos by Pinus radiata. South African J Bot 52:529-536

Richardson DM, Pyšek P, Rejmánek M, Barbour MG, Panetta FD, West CJ (2000) Naturalization and invasion of alien plants: concepts and definitions. Divers Distrib 6:93-107

Richardson DM, Rejmánek M (2004) Conifers as invasive aliens: a global survey and predictive framework. Divers Distrib 10:321-331

Richardson DM, Rejmánek M (2011) Trees and shrubs as invasive alien species-a global review. Divers Distrib 17:788-809

Robertson MP, Cumming GS, Erasmus BFN (2010) Getting the most out of atlas data. Divers Distrib 16:363-375

Rundel PW, Dickie IE and Richardson DM (2014) Tree invasions into treeless areas: mechanisms and ecosystem processes. Biol Invasions 16. doi:10.1007/s 10530-013-0614-9

Sebert-Cuvillier E, Paccaut F, Chabrerie O, Endels P, Goubet O, Decocq G (2007) Local population dynamics of an invasive tree species with a complex life-history cycle: a stochastic matrix model. Ecol Model 201:127-143

Simberloff D (2011) How common are invasion-induced ecosystem impacts? Biol Invasions 13:1255-1268 
Simberloff D, Gibbons L (2004) Now you see them, now you don't-population crashes of established introduced species. Biol Invasions 6:161-172

Smolik MG, Dullinger S, Essl F, Kleinbauer I, Leitner M, Peterseil J, Stadler LM, Vogl G (2010) Integrating species distribution models and interacting particle systems to predict the spread of an invasive alien plant. J Biogeogr 37:411-422

Stohlgren TJ, Pyšek P, Kartesz J, Nishino M, Pauchard A, Winter M, Pino J, Richardson DM, Wilson JRU, Murray BR, Phillips ML, Ming-yang L, Celesti-Grapow L, Font X (2011) Widespread plant species: natives versus aliens in our changing world. Biol Invasions 13:1931-1944

Thuiller W, Richardson DM, Pyšek P, Midgley GF, Hughes GO, Rouget M (2005) Niche-based modelling as a tool for predicting the risk of alien plant invasions at a global scale. Glob Change Biol 11:2234-2250

United Nations Environment Programme (2010) COP 10 Decision X/2. strategic plan for biodiversity 2011-2020 and the aichi biodiversity targets. Conference of the Parties to the Convention on Biological Diversity. Tenth meeting, Nagoya, 18-29 Oct 2010. http://www.cbd.int/doc/ decisions/cop-10/cop-10-dec-02-en.pdf

van Kleunen M, Weber E, Fischer M (2010) A meta-analysis of trait differences between invasive and non-invasive plant species. Ecol Lett 13:235-245

van Wilgen BW, Dyer C, Hoffmann JH, Ivey P, Le Maitre DC, Moore JL, Richardson DM, Rouget M, Wannenburgh A, Wilson JRU (2011) National-scale strategic approaches for managing introduced plants: insights from Australian acacias in South Africa. Divers Distrib 17:1060-1075

van Wilgen BW and Richardson DM (2014) Managing invasive alien trees: challenges and trade-offs. Biol Invasions 16 . doi:10.1007/s10530-013-0615-8

Vanden-Broeck A, Cox K, Michiels B, Verschelde P, Villar M (2012) With a little help from my friends: hybrid fertility of exotic Populus $\mathrm{x}$ canadensis enhanced by related native Populus nigra. Biol Invasions 14:1683-1696

Veldtman R, Chown SL, McGeoch MA (2010) Using scale-area curves to quantify the distribution, abundance and range expansion potential of an invasive species. Divers Distrib 16:159-169

Visser V, Langdon B, Pauchard A, Richardson DM (2014) Unlocking the potential of Google Earth as a tool in invasion science. Biol Invasions 16. doi:10.1007/s10530-0130604-y

Widrlechner MP, Thompson JR, Iles JKD, Dixon PM (2004) Models for predicting the risk of naturalization of non- native woody plants in Iowa. Journal of Environmental Horticulture 22:23-31

Williams JW, Jackson ST (2007) Novel climates, no-analog communities, and ecological surprises. Front Ecol Environ $5: 475-482$

Williamson MH, Fitter A (1996) The characters of successful invaders. Biol Conserv 78:163-170

Wilson JRU, Dormontt EE, Prentis PJ, Lowe AJ, Richardson DM (2009) Something in the way you move: dispersal pathways affect invasion success. Trends Ecol Evol 24:136-144

Wilson JRU, Gairifo C, Gibson MR, Arianoutsou M, Bakar BB, Baret S, Celesti-Grapow L, DiTomaso JM, Dufour-Dror JM, Kueffer C, Kull CA, Hoffmann JH, Impson FAC, Loope LL, Marchante E, Marchante H, Moore JL, Murphy D, Tassin J, Witt A, Zenni RD, Richardson DM (2011) Risk assessment, eradication, and biological control: global efforts to limit Australian acacia invasions. Divers Distrib 17:1030-1046

Wilson JRU, Richardson DM, Rouget M, Procheş Ş, Amis MA, Henderson L, Thuiller W (2007) Residence time and potential range: crucial considerations in modelling plant invasions. Divers Distrib 13:11-22

Wilson RJ, Thomas CD, Fox R, Roy DB, Kunin WE (2004) Spatial patterns in species distributions reveal biodiversity change. Nature 432:393-396

Worm B, Hilborn R, Baum J, Branch T, Collie J, Costello C, Fogarty M, Fulton E, Hutchings J, Jennings S, Jensen O, Lotze H, Mace P, McClanahan T, Minto C, Palumbi S, Parma A, Ricard D, Rosenberg A, Watson R, Zeller D (2009) Rebuilding global fisheries. Science 325:578-585

Zenni RD (in press) Analysis of introduction history of invasive plants in Brazil reveals patterns of association between biogeographical origin and reason for introduction. Austral Ecol: 10.1111/aec.12097

Zenni RD, J.-B. L, Lamarque LJ, Porté A (2014) Adaptive evolution, phenotypic plasticity and genotype-environment interactions in trees: implications for invasion biology. Biol Invasions 16. doi:10.1007/s10530-013-0607-8

Zenni RD, Nuñez MA (2013) The elephant in the room: the role of failed invasions in understanding invasion biology. Oikos 122:801-815

Zenni RD, Wilson JRU, Le Roux JJ, Richardson DM (2009) Evaluating the invasiveness of Acacia paradoxa in South Africa. South African J Botany 75:485-496

Zenni RD, Ziller SR (2011) An overview of invasive plants in Brazil. Brazilian J Botany 34:431-446 


\section{Supplementary Material 1: The knowledge of introduced flora in different countries}

The documented knowledge of introduced flora varies dramatically between countries. One of the most elaborated catalogues of non-native plants is for the Czech Republic (Pyšek et al. 2012). It lists 1454 taxa (mostly species, occasionally subspecies), including 71 trees and 139 shrubs, with information on: family, life history (semishrub, shrub, tree, etc.), residence time (archaeophyte, neophyte), invasion status (casual, naturalized, invasive), population group (18 categories characterizing establishment success, links to cultivation, and temporal trends), first record, abundance (single locality, rare, scattered, locally abundant, common, vanished), pathway of introduction (deliberate, accidental), region of origin, number of habitats in which the taxon grows (88 total), impact (ecological, economic), and source. Similar catalogues are also available for some other European countries (Celesti-Grapow et al. 2009; Medvecká et al. 2012; Reynolds 2002), though as shown by the DAISIE (Delivering Alien Invasive Species Inventories for Europe) project (Hulme et al. 2009) invasions are much less well documented in other countries. DAISIE is the most comprehensive regional inventory process, that took an approach for data collation (for a data rich and financially rich region) incorporated existing expertise (through use of an expertise registry) and databases as well as including potentially invasive alien species with a high likelihood of introduction from neighbouring countries (Hulme et al. 2009).

New Zealand's 2252 naturalized non-indigenous plant species (as of 2000) are also well characterized with compilations documenting ecology, introductions sources, and spatial spread by region (Gatehouse 2008; Howell 2008). Current efforts are focusing on finer scale mapping of distributions and consolidation of information from multiple sources (e.g. herbarium records, a national plot database (Wiser et al. 2001), Department of Conservation local office observations, and citizenscience observations captured via the internet). The challenge in these compilations is a lack of standards to facilitate ready integration of different data sources, difficulty in maintaining up-to-date information, and low reliability of some of the data, all of which limit further analysis and modelling. However, New Zealand has perhaps the best links between applied research, management, and policy. For example, a "Wilding Conifer Group" specifically monitors, maps, and reports on the invasive status of conifers, providing guidelines to prevent (http://www.nzpps.org/journal/61/nzpp 610910.pdf) and control (http://www.nzpps.org/journal/62/nzpp 623800.pdf) invasions.

By comparison Brazil has only started in the past decade to develop lists of alien plants and quantify the extent of invasions. A catalogue of invasive alien plants in natural habitats was published recently (Zenni and Ziller 2011), and some states published official lists of invasive species (e.g. Paraná, Santa 
Catarina, and São Paulo). A national database of invasive alien species in Brazil has been constructed (Zenni and Ziller, 2013) - with information on taxonomy, biology, introduction history, impacts, and occurrences-but the data are mostly observational presence records without measures of local abundance, extent, spread, and are often not linked to physical herbarium records. Parallel to this large-scale rough collection of cases of invasions, a few studies are starting to be published with local detailed evaluations of invasions abundance, extent, spread, and impact (de Abreu and Durigan 2011; Mengardo et al. 2012; Zenni and Simberloff 2013). With more time and more work, the local more detailed studies will start to feed regional and national assessments of invasions to improve management, research, and public policy.

With developments towards standard reporting of biodiversity information (e.g. the Darwin Core, http://rs.tdwg.org/dwc/), lists in Europe, New Zealand, and Brazil should become increasingly crosscompatible. Ideally such lists hould also include information on invasions that is directly relevant to management and policy decisions (e.g. Appendices 1 and 2). However, the documentation of introduced flora in most countries only extends to economically important species and their associated pests and diseases (e.g. see http://www.cabi.org/isc/).

References

de Abreu RCR and Durigan G (2011) Changes in the plant community of a Brazilian grassland savannah after 22 years of invasion by Pinus elliottii Engelm. Plant Ecology \& Diversity 4: 269-278

Celesti-Grapow L, Alessandrini A, Arrigoni PV, Banfi E, Bernardo L, Bovio M, Brundu G, Cagiotti MR, Camarda I, Carli E, Conti F, Fascetti S, Galasso G, Gubellini L, La Valva V, Lucchese F, Marchiori S, Mazzola P, Peccenini S, Poldini L, Pretto F, Prosser F, Siniscalco C, Villani MC, Viegi L, Wilhalm T and Blasi C (2009) Inventory of the non-native flora of Italy. Plant Biosystems 143: 386-430

Gatehouse HAW (2008) Ecology of the naturalisation and geographic distribution of the nonindigenous seed plant species of New Zealand, PhD Thesis, Lincoln University, Lincoln, New Zealand, http://hdl.handle.net/10182/1009

Howell CJ (2008) Consolidated list of environmental weeds in New Zealand. DOC Research \& Development Series 292-42

Hulme PE, Roy DB, Cunha T and Larsson T-B (2009) A pan-European inventory of alien species: rationale, implementation and implications for managing biological invasions. DAISIE: Handbook of alien species in Europe, Springer, Dordrecht. 
Medvecká J, Kliment J, Májeková J, Halada L', Zaliberová M, Gojdičová E, Feráková V and Jarolímek I (2012) Inventory of the alien flora of Slovakia. Preslia 84: 257-309

Mengardo ALT, Figueiredo CL, Tambosi LR and Pivello VR (2012) Comparing the establishment of an invasive and an endemic palm species in the Atlantic rainforest. Plant Ecology \& Diversity 5: 345-354

Pyšek P, Danihelka J, Sádlo J, Chrtek J, Chytrý M, Jarošík V, Kaplan Z, Krahulec F, Moravcová L, Pergl J, Štajerová K and Tichý L (2012) Catalogue of alien plants of the Czech Republic (2nd edition): checklist update, taxonomic diversity and invasion patterns. Preslia 84: 155-255

Reynolds SCP (2002) A Catalogue of Alien Plants in Ireland, National Botanic Gardens, Glasnevin.

Wiser SK, Bellingham PJ and Burrows LE (2001) Managing biodiversity information: development of New Zealand's National Vegetation Survey databank. New Zealand Journal of Ecology 25: 1-17

Zenni RD and Simberloff D (2013) Number of source populations as a potential driver of pine invasions in Brazil. Biological Invasions 15: 1623-1639

Zenni RD and Ziller SR (2011) An overview of invasive plants in Brazil. Brazilian Journal of Botany 34: 431-446 
Supplementary Material 2: Method for categorizing trees into Blackburn et al. 2011's unified framework for biological invasions (Table S2a), and a fieldguide for how to categories invasions (Table S2b) .

Table S2a. We focus on determining the category of species at a global level, but, as the categories are event specific, adjustments are needed for local listing. There are also inevitable temporal changes in categories, and uncertainty in most cases. Our recommendation would be to either present a range of possible categories or present the category furthest down the list for which solid evidence is available (though note an introduction event need not follow the categories in the order presented here).

\begin{tabular}{|c|c|c|c|}
\hline Category & Formal definition as per Blackburn et al. (2011) & Interpretation for trees & Measurements \\
\hline A & Not transported beyond limits of native range. & $\begin{array}{l}\text { Not introduced } \\
\text { No evidence of the species having been moved } \\
\text { outside native range (or conversely no record of } \\
\text { import into a specified range). A separate } \\
\text { category (A2) is recommended where a species } \\
\text { had been moved but there is no evidence of the } \\
\text { species still being found outside its native range } \\
\text { (or in a specified area). }\end{array}$ & $\begin{array}{l}\text { No export records of seed or other vegetative parts (or import permits } \\
\text { from a specified region) } \\
\text { No herbarium records collected outside native range. } \\
\text { No record of sale in horticulture or of in forestry trials. } \\
\text { No anecdotal data on delivery or accidental introduction. }\end{array}$ \\
\hline B1 & $\begin{array}{l}\text { Individuals transported beyond limits of native range, and in } \\
\text { captivity or quarantine (i.e. individuals provided with conditions } \\
\text { suitable for them, but explicit measures of containment are in } \\
\text { place) }\end{array}$ & \multirow{3}{*}{$\begin{array}{l}\text { Introduced-first phase } \\
\text { Almost all tree introductions for forestry and } \\
\text { horticultural are B2, with strong evidence needed } \\
\text { to place them in a different category. Exceptions } \\
\text { include GMO trees or specific biofuel introductions } \\
\text { where strict containment and quarantine } \\
\text { measures are in place B1, or tree seeds } \\
\text { introduced as contaminants, e.g. through road } \\
\text { machinery B3. }\end{array}$} & \multirow{3}{*}{$\begin{array}{l}\text { B2 if } \\
\text { - physical specimen collected outside native range, or } \\
\text { unless also have, } \\
\text { - evidence of a specific managed trials where seed-set is } \\
\text { prevented or an effective management plan is in place to } \\
\text { prevent recruitment outside a specified area (B1); } \\
\text { documented release into the wild, e.g. for restoration or land } \\
\text { reclamation, or by naturalization societies (B3) }\end{array}$} \\
\hline B2 & $\begin{array}{l}\text { Individuals transported beyond limits of native range, and in } \\
\text { cultivation (i.e. individuals provided with conditions suitable for } \\
\text { them but explicit measures to prevent dispersal are limited at } \\
\text { best) }\end{array}$ & & \\
\hline B3 & $\begin{array}{l}\text { Individuals transported beyond limits of native range, and } \\
\text { directly released into novel environment }\end{array}$ & & \\
\hline Co & $\begin{array}{l}\text { Individuals released into the wild (i.e. outside of captivity or } \\
\text { cultivation) in location where introduced, but incapable of } \\
\text { surviving for a significant period }\end{array}$ & \multirow{3}{*}{$\begin{array}{l}\text { Introduced-second phase } \\
\text { Some recruitment outside cultivation, but } \\
\text { something prevents a self-sustaining population. } \\
\text { Given most trees are deliberate introductions, the } \\
\text { separation between cultivated and self-recruiting } \\
\text { individuals needs to be clearly made. Examples of } \\
\text { populations in this phase would include forestry } \\
\text { plantations or ornamental trees where adult } \\
\text { survival in cultivation is high, but due to stress } \\
\text { factors like drought or herbivory, plants rarely } \\
\text { survive to maturity. }\end{array}$} & \multirow{3}{*}{ 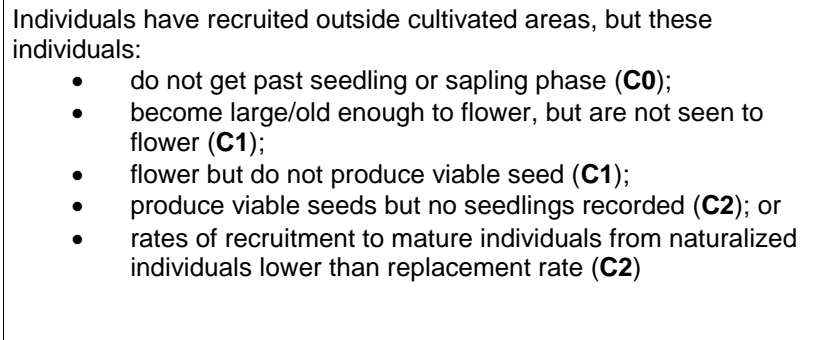 } \\
\hline C1 & $\begin{array}{l}\text { Individuals surviving in the wild (i.e. outside of captivity or } \\
\text { cultivation) in location where introduced, no reproduction }\end{array}$ & & \\
\hline C2 & $\begin{array}{l}\text { Individuals surviving in the wild in location where introduced, } \\
\text { reproduction occurring, but population not self-sustaining }\end{array}$ & & \\
\hline
\end{tabular}




\begin{tabular}{|c|c|c|c|}
\hline Category & Formal definition as per Blackburn et al. (2011) & Interpretation for trees & Measurements \\
\hline C3 & $\begin{array}{l}\text { Individuals surviving in the wild in location where introduced, } \\
\text { reproduction occurring, and population self-sustaining }\end{array}$ & $\begin{array}{l}\text { Naturalized } \\
\text { Individuals have recruited outside cultivated } \\
\text { areas, and these recruiting individuals have } \\
\text { produced mature individuals }\end{array}$ & $\begin{array}{l}\text { For trees it can be very difficult to separate } \mathbf{C 2} \text { from } \mathbf{C 3} \text {-propagules } \\
\text { released from cultivated individuals can be hard to distinguish from } \\
\text { propagules released from self-recruiting individuals. If none of the } \\
\text { original planted individuals remain but recruitment still occurring the } \\
\text { population is likely to be C3, though a persistent seed-bank could } \\
\text { make it difficult to detect a population in terminal decline. We } \\
\text { recommend C3 in most instances unless there is evidence that the } \\
\text { population would not be naturally self-sustaining. }\end{array}$ \\
\hline D1 & $\begin{array}{l}\text { Self-sustaining population in the wild, with individuals surviving a } \\
\text { significant distance from the original point of introduction }\end{array}$ & \multirow{2}{*}{$\begin{array}{l}\text { Invasive } \\
\text { Individuals outside cultivation are significantly } \\
\text { further from source populations than could be } \\
\text { explained simply by localized below-canopy } \\
\text { recruitment, i.e. there is dispersal. }\end{array}$} & \multirow{2}{*}{$\begin{array}{l}\text { Individuals have spread }>100 \mathrm{~m} \text { in }<50 y r s \text {. } \\
\text { This can be confounded by consistency of establishment in time and } \\
\text { space. }\end{array}$} \\
\hline D2 & $\begin{array}{l}\text { Self-sustaining population in the wild, with individuals surviving } \\
\text { and reproducing a significant distance from the original point of } \\
\text { introduction }\end{array}$ & & \\
\hline E & $\begin{array}{l}\text { Fully invasive species, with individuals dispersing, surviving and } \\
\text { reproducing at multiple sites across a greater or lesser spectrum } \\
\text { of habitats and extent of occurrence }\end{array}$ & $\begin{array}{l}\text { Invasive } \\
\text { There are several invasion foci, resulting from } \\
\text { multiple events of successful dispersal over } \\
\text { multiple ranges enough to occupy a large } \\
\text { landscape. The whole invasion would be defined } \\
\text { as several populations (or meta-populations), or } \\
\text { for a continuous population the current range can } \\
\text { only be explained by seeds dispersal from adult } \\
\text { individuals far removed from the original point of } \\
\text { introduction. The practical implication is that } \\
\text { considerable effort would be required for } \\
\text { eradication to succeed. }\end{array}$ & $\begin{array}{l}\text { How frequent is this pattern in a biogeographic region. Does it occur in } \\
\text { multiple ecosystems/vegetation types? How spread is the invasion } \\
\text { across environmental gradients (e.g. altitude)? } \\
\text { The invasion occupies several sites at a resolution of } 100 \\
\mathrm{~km}^{2} \text {, i.e. invasive populations are separated by at least } \\
\sim 10 \mathrm{~km} \text {, or } \\
\text { Is the species capable of invading a landscape? } \\
\text { A convex hull of the invasion covers an area of }>1000 \mathrm{ha} \text {, } \\
\text { i.e. plants have spread at least } 3 \mathrm{~km} \text { from the point of } \\
\text { introduction. }\end{array}$ \\
\hline
\end{tabular}

Table S2b: A set of questions to determine the status of an introduced tree based on distance from site of planting. These basic questions can also be expanded upon by providing quantitative information on how far away, over what time interval, and densities or canopy covers for each category. In answering these questions it is possible to evaluate the status of a species according to the Table S2a.

\begin{tabular}{|l|c|c|c|c|c|c|}
\hline Distance from known or putative site of original planting & \multicolumn{2}{|c|}{$\begin{array}{c}2 \times \text { crown } \\
\text { radius }\end{array}$} & \multicolumn{2}{|c|}{$\begin{array}{c}2 \times \text { crown } \\
\text { radius to } \\
100 m\end{array}$} & \multicolumn{2}{|c|}{$>100 \mathrm{~m}$} \\
\hline Do individuals survive after planting or accidental establishment? & yes & no & \multicolumn{3}{|c|}{ N/A } \\
\hline Are viable seeds or other propagules produced and dispersed? & yes & no & yes & no & yes & no \\
\hline Is there a long-lasting seed-bank? & yes & no & yes & no & yes & no \\
\hline Are seedlings or vegetative offspring present? & yes & no & yes & no & yes & no \\
\hline Do seedlings /vegetative offspring survive for more than one year? & yes & no & yes & no & yes & no \\
\hline Is there survival to reproductive maturity? & yes & no & yes & no & yes & no \\
\hline
\end{tabular}


Examples of using the field guide (Table S2b) to place species in a category according to Blackburn (Table S2a) Assessment:

\begin{tabular}{|l|c|c|c|}
\hline Distance from known or putative site of original planting & $\begin{array}{c}2 \times \text { crown } \\
\text { radius }\end{array}$ & $\begin{array}{c}2 \times \text { crown } \\
\text { radius to } \\
100 m\end{array}$ & $>100 \mathrm{~m}$ \\
\hline Do individuals survive after planting or accidental establishment? & & no & \multicolumn{2}{|c|}{$\mathrm{N} / \mathrm{A}$} \\
\hline
\end{tabular}

Result: B1-C0. Further clarification would depend on the position of the planting in the landscape

Assessment:

\begin{tabular}{|l|c|c|c|c|c|c|}
\hline Distance from known or putative site of original planting & \multicolumn{2}{|c|}{$\begin{array}{c}2 \times \text { crown } \\
\text { radius }\end{array}$} & \multicolumn{2}{|c|}{$\begin{array}{c}2 \times \text { crown } \\
\text { radius to } \\
100 \mathrm{~m}\end{array}$} & \multicolumn{2}{|c|}{$>100 \mathrm{~m}$} \\
\hline Do individuals survive after planting or accidental establishment? & yes & & & \multicolumn{3}{|c|}{ N/A } \\
\hline Are viable seeds or other propagules produced and dispersed? & yes & & N/A & N/A & N/A & N/A \\
\hline Is there a long-lasting seed-bank? & & no & & no & & no \\
\hline Are seedlings or vegetative offspring present? & yes & & yes & & yes & \\
\hline Do seedlings /vegetative offspring survive for more than one year? & yes & & yes & & yes & \\
\hline Is there survival to reproductive maturity? & & no & & no & & no \\
\hline
\end{tabular}

Result: C2. If, with time, some recruits reproduce then the population would become naturalised.

Assessment:

\begin{tabular}{|c|c|c|c|c|c|}
\hline \multirow{3}{*}{$\begin{array}{l}\text { Distance from known or putative site of original planting } \\
\text { Do individuals survive after planting or accidental establishment? } \\
\text { Are viable seeds or other propagules produced and dispersed? }\end{array}$} & $\begin{array}{l}2 \times \text { crown } \\
\text { radius }\end{array}$ & \multicolumn{2}{|c|}{$\begin{array}{l}2 \times \text { crown } \\
\text { radius to } \\
100 \mathrm{~m}\end{array}$} & \multicolumn{2}{|c|}{$>100 m$} \\
\hline & yes & \multicolumn{4}{|c|}{ N/A } \\
\hline & yes & yes & & yes & \\
\hline Is there a long-lasting seed-bank? & yes & & no & & no \\
\hline Are seedlings or vegetative offspring present? & yes & yes & & yes & \\
\hline Do seedlings /vegetative offspring survive for more than one year? & yes & yes & & yes & \\
\hline Is there survival to reproductive maturity? & yes & yes & & yes & \\
\hline
\end{tabular}

Result: D2-E. Population is invasive, though might still be restricted to a single site, would need to identify other populations before classifying as E. 